\title{
Cave lion (Panthera spelaea) from the Pleistocene of Chuvashiya, European Russia
}

\author{
Gennady F. Baryshnikov \& Ekaterina A. Petrova
}

\begin{abstract}
Two mandibles of the cave lion referred to the nominotypical subspecies Panthera spelaea spelaea are recorded for the first time in the Pleistocene of Chuvashiya. The distribution map of this subspecies in the Eastern Europe is given.
\end{abstract}

KEY WORDS: Panthera spelaea, Pleistocene, Eastern Europe.

Gennady F. Baryshnikov [G_Baryshnikov@mail.ru], Zoological Institute, Russian Academy of Sciences, Universitetskaya nab. 1, Saint Petersburg 199034, Russia; Ekaterina A. Petrova [mammut2003@mail.ru], EcologicalBiological Centre, ul. Cooperativnaya 4, Cheboksary 428000, Russia.

\section{Пещерный лев (Panthera spelaea) из плейстоцена Чувашии, Европейская Россия}

\section{Г.Ф. Барышников, Е.А. Петрова}

РЕЗЮМЕ. Две нижнечелюстные кости пещерного льва, впервые найденные в плейстоцене Чувашии, отнесены к номинативному подвиду Panthera spelaea spelaea. Приведена карта распространения этого подвида в Восточной Европе.

КЛЮЧЕВЫЕ СЛОВА: Panthera spelaea, плейстоцен, Восточная Европа.

\section{Introduction}

The cave lion (Panthera spelaea (Goldfuss, 1810)) was widely distributed in the Pleistocene of Holarctic from British Isles to Alaska and Yukon Territory. This animal occupied an important position in the northern ecosystems, being at the top of the trophic pyramid of the mammoth fauna (Vereshchagin \& Baryshnikov, 1992).

The taxonomic position of cave lion is variously interpreted. Some authors regard it as a northern subspecies of the recent species P. leo (L., 1758) (Kurtén, 1968; Kurtén \& Andersen, 1980; Yamaguchi et al., 2004), which is testified by molecular evidence (Burger et al., 2004). Other researchers, mainly Russian ones, consider the cave lion to be a distinct species (Vereshchagin, 1971; Baryshnikov \& Boeskorov, 2001; Sotnikova \& Nikolskiy, 2006).

Bones and teeth of P. spelaea are found in many localities of the Middle and Late Pleistocene of the Northern Eurasia, being there, as a rule, very scant. Vereshchagin (1971) provided a survey of findings from the territory of the former USSR. These data are supplemented here by the information on two mandibles of the cave lion from European Russia, recorded in the territory of Chuvashiya, in the basin of the Volga River. One is kept at the Chuvashiyan National Museum, Cheboksary (CHNM), another is stored in the private collection of the same city. This communication deals with their description.
For the comparison, collections of Zoological Institute, Russian Academy of Sciences in Saint Petersburg (ZIN), Geological-Mineralogical Museum of Kazan University in Kazan (GMMK), Nature History Museum in London (NHM), Muséum National d'Histoire Naturelle in Paris (MNHN), and Institute of Systematics and Evolution of Animals in Krakow (ISEA) were used.

\section{Description}

The right mandible (CHNM 9105) originates from the territory of Chuvashiya, the exact place of its discovery being, however, unknown. The canine, cheek teeth $\mathrm{p} 4$ and $\mathrm{m} 1$, and alveoli of $\mathrm{p} 3$ are present (Fig. 1). The anterior mental foramen is doubled; posterior one is situated below the p3. Mental prominence is well developed. Ventral mandibular margin is straight. The ratio between the $\mathrm{m} 1$ length and the length of $\mathrm{c} 1-\mathrm{m} 1$ row is $38.0 \%$.

The second finding is represented by the fragment of right mandible (Fig. 2), which was recovered on the bank of Bol'shaya Shatma River in Krasnoarmeisk District of Chuvashiya in the July of 2005. Its mandibular ramus with coronoid, condylar, and angular processes are broken off. The dentition is represented by the incisor i3, canine, cheek teeth $\mathrm{p} 4$ and $\mathrm{m} 1$, and alveoli of p3. The length and width of the i3 are $8.6 \mathrm{~mm}$ and 8.1 $\mathrm{mm}$ correspondingly. Postcanine diastema is moderate, mental prominence is well developed. The ventral mar- 


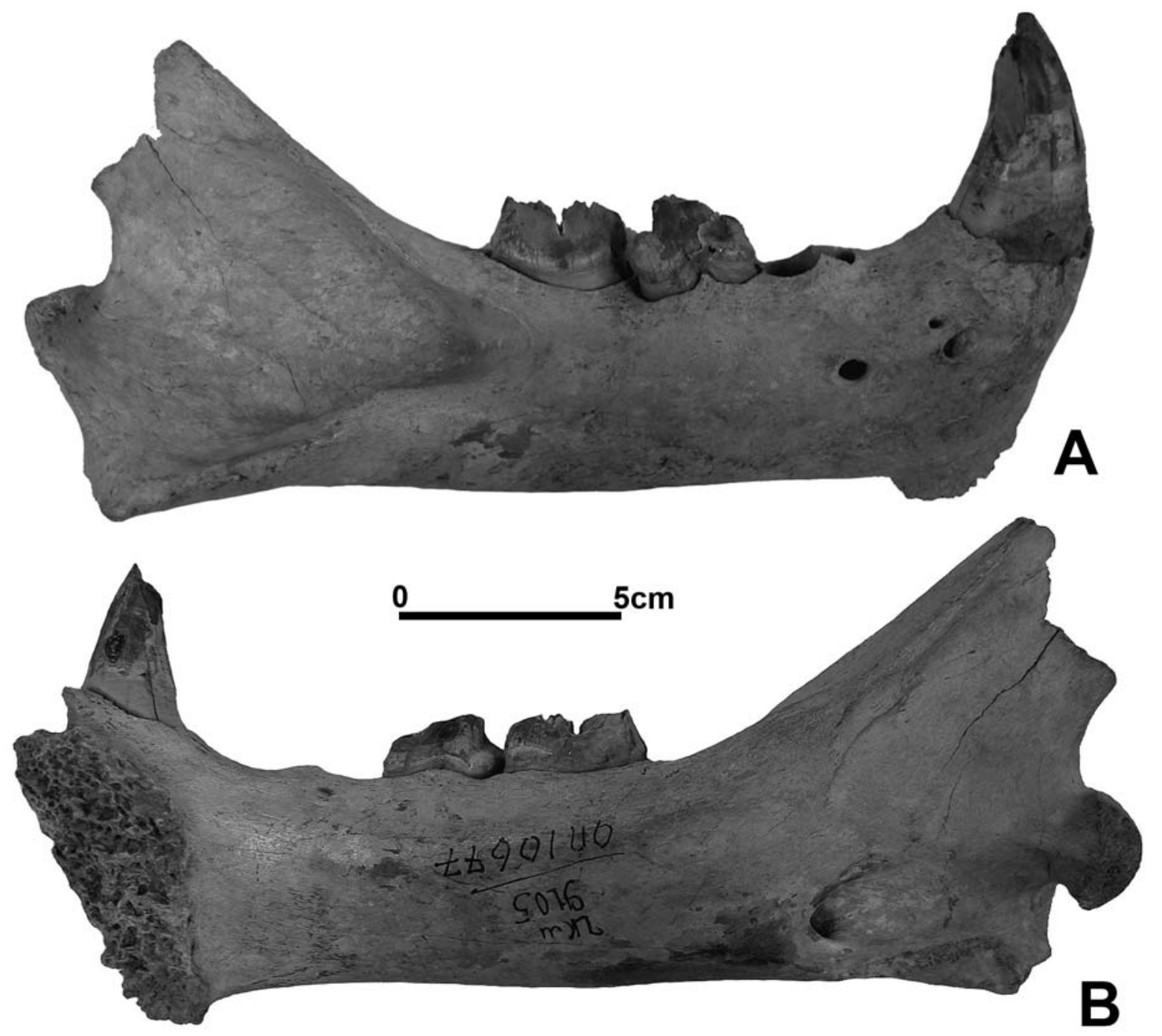

Figure 1. Mandible of Panthera spelaea spelaea from Chuvashiya (unknown locality), CHNM 9105, in labial (A) and lingual (B) view.

gin of the mandible below the lower carnassial tooth $\mathrm{m} 1$ is weakly convex, which is characteristic of the cave lion (Vereshchagin, 1971). The ratio between the m1 length and the length of $\mathrm{c} 1-\mathrm{m} 1$ row is $38.7 \%$.

Other examined mandibles of the cave lion from the various localities in Western and Eastern Europe markedly differ in dimensions, which presumably reflects sexual variation (Tabs 1 and 2). The presence of the sexual dimorphism in the cave lion has been established by Turner (1984) on the basis of difference in size of the upper canine $(\mathrm{C} 1)$, the lower canine $(\mathrm{c} 1)$, and the lower carnassial tooth $(\mathrm{m} 1)$ between males and females. As in the recent $P$. leo, males of $P$. spelaea exceeded females in the size.

The mandibles, whose width of lower canine measured at the level of the lower margin of enamel exceeds $19.5 \mathrm{~mm}$, are ascribed by us to males. In these mandibles, lower carnassial tooth $\mathrm{m} 1$ exceeds $31 \mathrm{~mm}$ in the length. Therefore, the minimum value of the $\mathrm{m} 1$ length in examined specimens coincides with the mean of this length (30.73 mm, $\mathrm{n}=77$ ) calculated by Kurtén (1985) for the European males of $P$. spelaea. Judging from rather small size of the lower canine and small length of $\mathrm{m} 1$, both mandibles from Chuvashiya belong to females.

Stratigraphical position of the Chuvashiyan samples is indefinite. These mandibles are morphometrically very close to the specimen found near Mansurovo village at the mouth of the Kama River (Averianov et al., 1992). Similar dimensions are established for the cave lion mandibles from other localities of Western and Eastern Europe, including Zoolithen Cave, which is the type locality for P. spelaea (Tabs 1 and 2).

The right mandible with broken $\mathrm{m} 1$ from the early Middle Pleistocene of Forest Bed (NHM M6165) in 


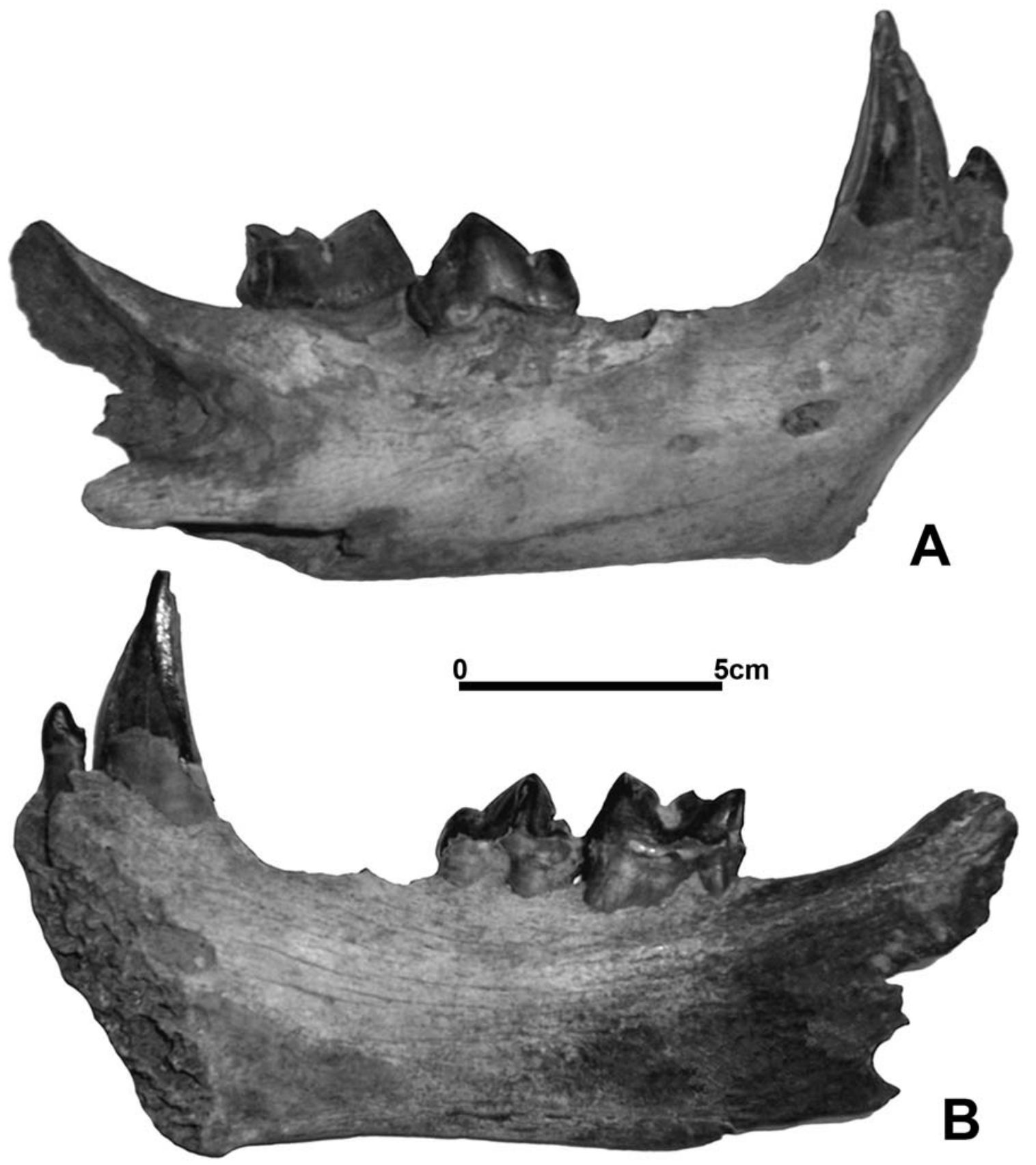

Figure 2. Mandibular fragment of Panthera spelaea spelaea from Bolshaya Shat'ma River, Chuvashiya, private collection, in labial (A) and lingual (B) view.

England possesses the lower canine (length $26.5 \mathrm{~mm}$, width $19.1 \mathrm{~mm}$ ) corresponding to a female. In the length of the $\mathrm{c} 1-\mathrm{m} 1$ row $(132.7 \mathrm{~mm})$ and length of the $\mathrm{p} 3-\mathrm{m} 1$ row $(81.5 \mathrm{~mm})$, this specimen is only inconspicuously larger than female specimens of $P$. spelaea from the European Late Pleistocene. Thus, the mandibular size does not seem to be a reliable criterion in determining the geological age of the cave lion remains. Meantime, the index of correlation between the width of the lower carnassial tooth $\mathrm{ml}$ and its length is treated to be considerably more important for the geological attribution of cave lion findings. For the examined mandibles it is varied from $46.4 \%$ to $54.7 \%, 49.8 \%$ in average $(\mathrm{n}=20)$. In the specimens from the early Middle Pleistocene localities of Europe, the value of this index is considerably higher, varying from $53.5 \%$ to $56.5 \%$ and constituting in average $55.5 \%(n=7)$ (Schütt \& Hemmer, 1978). Similar index has been obtained by us for the isolated lower carnassial tooth $\mathrm{m} 1$ (NHM F66, length $30.5 \mathrm{~mm}$, width $17.0 \mathrm{~mm}$ ) from early Middle 


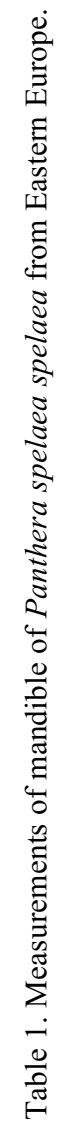

\begin{tabular}{|c|c|c|c|c|c|c|c|c|c|c|c|c|c|c|c|c|}
\hline & 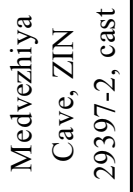 & $=$ & $\stackrel{\text { I }}{ \pm}$ & 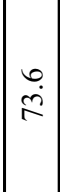 & ‡ & 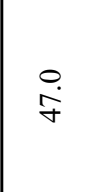 & & & & & & 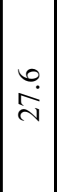 & $\begin{array}{l}\ddot{g} \\
\dot{g}\end{array}$ & $\overrightarrow{\dot{d}}$ & 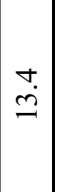 & $\overrightarrow{\dot{B}}$ \\
\hline \multirow[t]{3}{*}{$\begin{array}{l}\frac{n}{5} \\
\frac{\pi}{5}\end{array}$} & \multirow{3}{*}{ 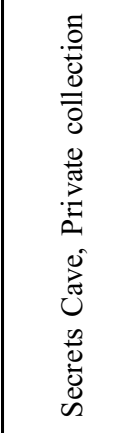 } & $\begin{array}{l}n \\
\tilde{\infty} \\
\sim\end{array}$ & ㅇ. & $\begin{array}{l}n \\
\infty \\
\infty\end{array}$ & $\begin{array}{l}\text { İ } \\
\text { İ }\end{array}$ & $\frac{\infty}{\dot{\sigma}}$ & & ते & $\frac{\sim}{\sim}$ & & & $\begin{array}{l}n \\
0 \\
\infty\end{array}$ & $\underline{i n}$ & $\mid \begin{array}{c}0 \\
\dot{m}\end{array}$ & $\begin{array}{l}n \\
\stackrel{n}{=}\end{array}$ & $\stackrel{\circ}{\stackrel{n}{n}}$ \\
\hline & & $\begin{array}{l}0 \\
\dot{d} \\
\dot{d}\end{array}$ & 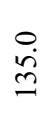 & ?. & $\hat{b}$ & 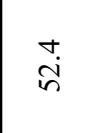 & & $\begin{array}{l}\infty \\
\sim \\
\sim\end{array}$ & 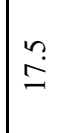 & $\begin{array}{l}0 \\
\infty \\
\infty\end{array}$ & $\overline{0}$ & $\overrightarrow{\vec{\lambda}}$ & $\stackrel{\sim}{\vec{m}}$ & $\begin{array}{l}\dot{a} \\
\stackrel{\vec{\lambda}}{ }\end{array}$ & $\begin{array}{l}\infty \\
\dot{ \pm}\end{array}$ & ?̊. \\
\hline & & $\begin{array}{l}\dot{0} \\
\dot{\leftrightarrow} \\
i\end{array}$ & $\stackrel{\text { Oे }}{\dot{q}}$ & $\stackrel{\substack{\infty \\
\infty}}{\infty}$ & $\begin{array}{c}\text { o. } \\
\stackrel{\infty}{n}\end{array}$ & $\begin{array}{l}\text { in } \\
\text { in }\end{array}$ & & & . & $\begin{array}{l}\infty \\
\infty \\
\infty\end{array}$ & $\stackrel{\circ}{\circ}$ & $\mid \begin{array}{l}0 \\
\infty \\
\infty \\
i\end{array}$ & $\stackrel{n}{\rho}$ & $\overrightarrow{\dot{m}}$ & $\begin{array}{l}\infty \\
\dot{ \pm}\end{array}$ & 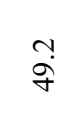 \\
\hline \multirow{4}{*}{ 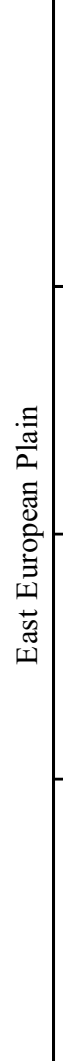 } & 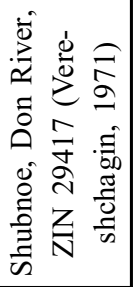 & 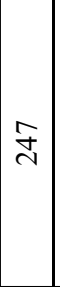 & 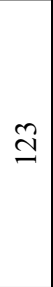 & 1 & 1 & 1 & & $\stackrel{\infty}{\sim}$ & 2 & & & $\stackrel{\circ}{\sim}$ & 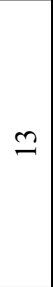 & $\underset{\infty}{\infty} \mid$ & 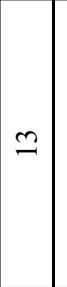 & 它 \\
\hline & 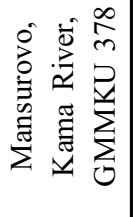 & 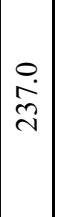 & $\begin{array}{l}m \\
\stackrel{i}{S}\end{array}$ & $\begin{array}{l}0 \\
i\end{array}$ & in & $\begin{array}{l}n \\
\tilde{r}\end{array}$ & & & & & & & & $\begin{array}{c}\dot{r} \\
\dot{n}\end{array}$ & $\ddot{\ddot{g}}$ & $\vec{b}$ \\
\hline & 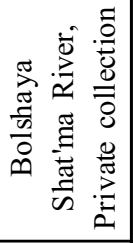 & 1 & $\stackrel{\stackrel{\sim}{\Xi}}{\simeq}$ & $\ddot{i}$ & 1 & 1 & & $\begin{array}{l}0 \\
\dot{\leftrightarrow}\end{array}$ & $\stackrel{n}{\simeq}$ & & & $\mid \begin{array}{c}\stackrel{\sim}{\sim} \\
\stackrel{\sim}{\sim}\end{array}$ & $\stackrel{\sim}{\beth}$ & $\left|\begin{array}{c}\sim \\
\infty \\
\sim \\
\sim\end{array}\right|$ & $\begin{array}{l}0 \\
\stackrel{2}{2}\end{array}$ & $\underset{\infty}{\stackrel{\infty}{+}}$ \\
\hline & 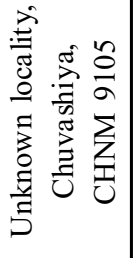 & 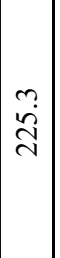 & 1 & $\begin{array}{l}\dot{\sigma} \\
\stackrel{0}{0}\end{array}$ & $\begin{array}{l}\bar{m} \\
\stackrel{g}{\sigma}\end{array}$ & 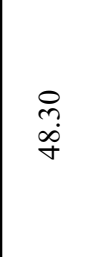 & & $\stackrel{\check{\sim}}{\stackrel{\sim}{2}}$ & $\vec{\infty}$ & & & $\mid \begin{array}{l}n \\
2 \\
n\end{array}$ & $\begin{array}{l}\tilde{i} \\
\simeq\end{array}$ & $\begin{array}{l}\ddot{i} \\
\ddot{i}\end{array}$ & $\overrightarrow{ \pm}$ & $\begin{array}{l}0 \\
\stackrel{0}{+}\end{array}$ \\
\hline \multicolumn{2}{|c|}{ 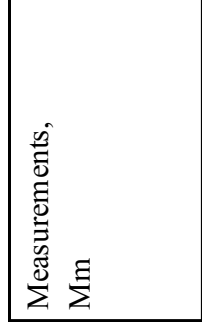 } & 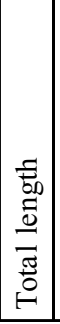 & 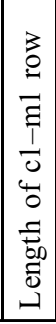 & 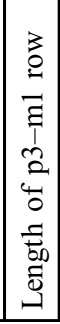 & 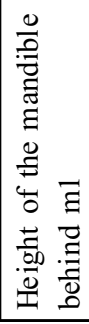 & 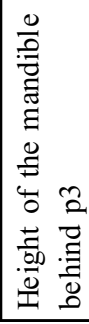 & 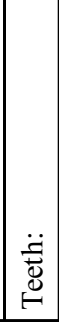 & 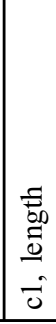 & $\frac{F}{\frac{E}{3}}$ & 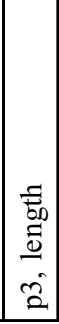 & $\frac{\bar{E}}{\frac{D}{3}}$ & 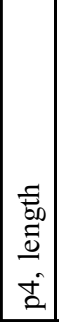 & $\begin{array}{l}\frac{5}{0} \\
\frac{0}{3}\end{array}$ & 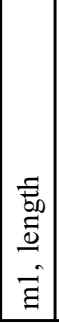 & $\frac{\bar{E}}{\frac{D}{3}}$ & 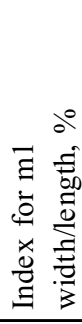 \\
\hline
\end{tabular}




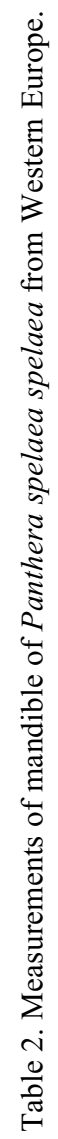

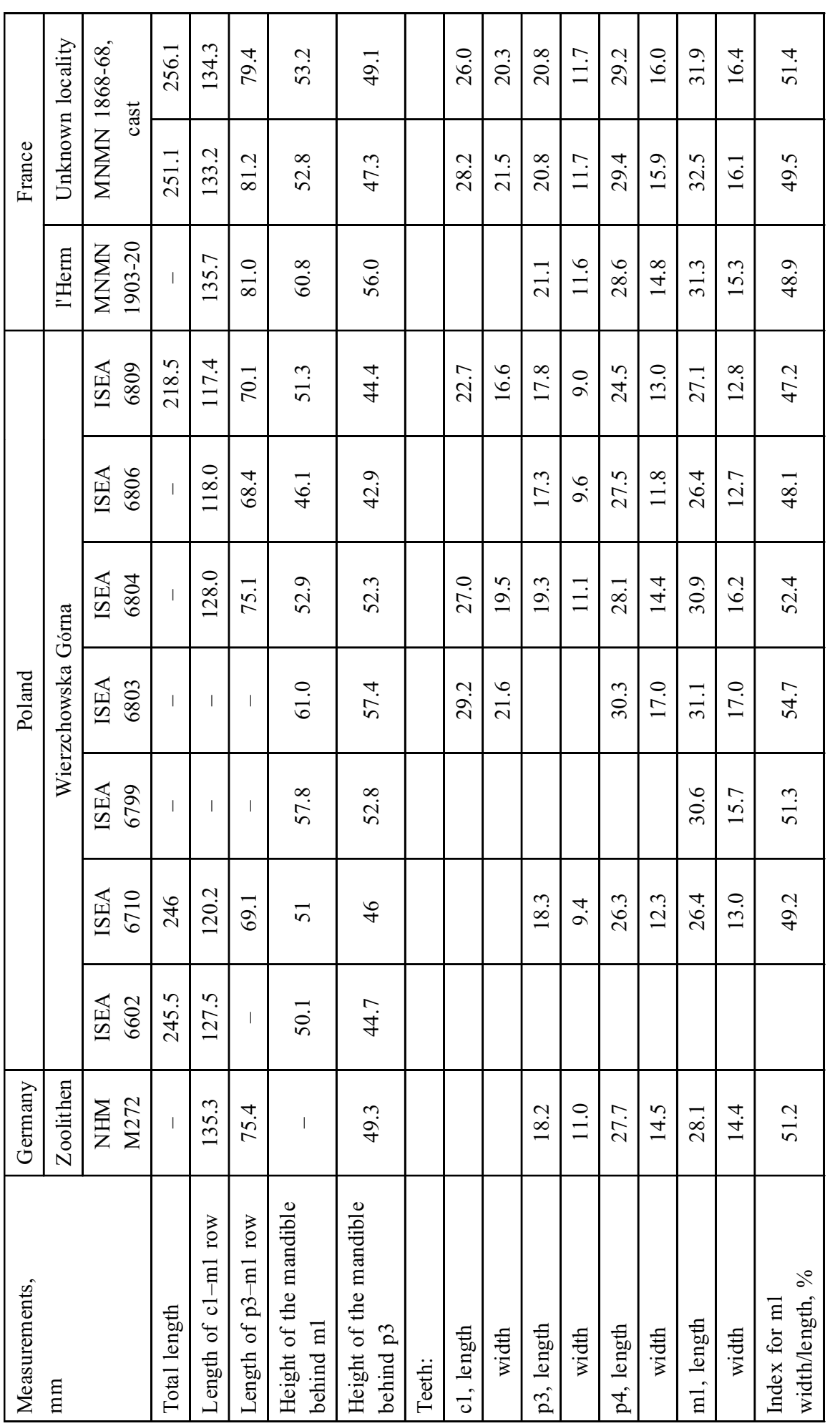




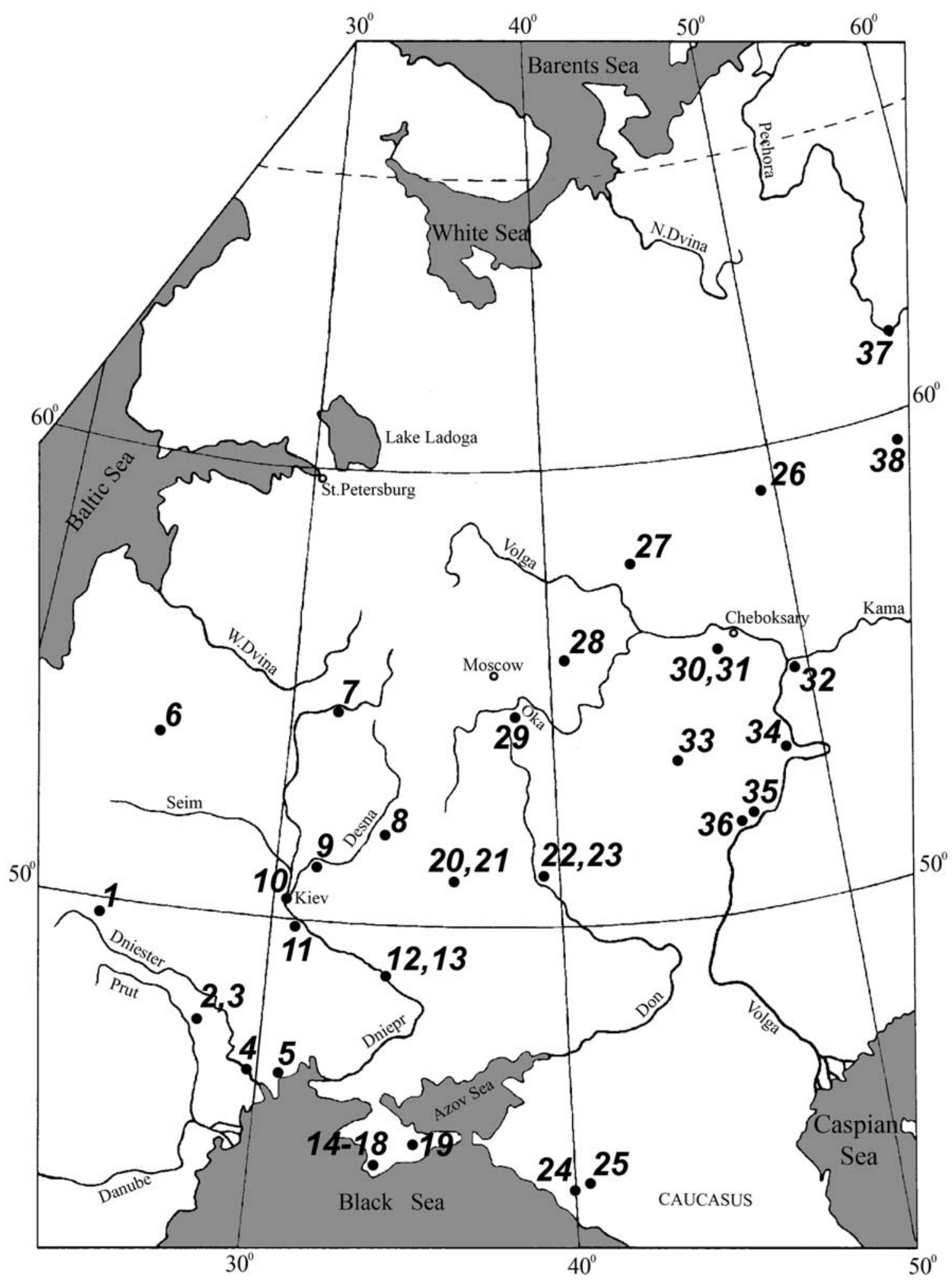

Figure 3. Map of localities of Panthera spelaea in the late Middle Pleistocene and Late Pleistocene of Eastern Europe (according to Sukachev et al., 1966; Vereshchagin, 1971; Soffer, 1985; Kalinovski \& Kuzmina, 1993; Baryshnikov et al., 1996; Averianov et al., 1999; Enloe et al., 2000; Chubur, 2001; Burova, 2002; Sotnikova \& Nikolskiy, 2006; and original data). 
Pleistocene locality of Westbury Quarry Cave in England $(55.7 \%)$.

There are two currently recognized subspecies of $P$. spelaea in Europe (Schütt \& Hemmer, 1978): the early Middle Pleistocene P. s. fossilis (von Reichenau, 1906) and later $P$. s. spelaea (Goldfuss, 1810) occurring in the Europe from the late Middle Pleistocene to the end of Pleistocene. The cave lion from Chuvashiya seems to belong to the nominotypical subspecies. It should be mentioned that these subspecies are occasionally considered as distinct species (Sotnikova \& Nikolskiy, 2006).

\section{Discussion}

The examined first findings of the cave lion $(P$. spelaea) in Chuvashiya appear to be among the northernmost ones for the East European Plain.

The mapping of localities with presence of the cave lion remains shows that this animal was widespread in the Eastern Europe, with exception of the area covered by the ice sheet (Fig. 3). In the western part of Eastern Europe, the localities do not occur northwards to $54^{\circ} \mathrm{N}$, being spread in the central part as far as $58^{\circ} \mathrm{N}$ and approaching $62^{\circ} \mathrm{N}$ in the North Ural (Medvezhiya Cave).

Unlike the cave bear (Ursus spelaeus Rosenmüller, 1794) and cave hyena (Crocuta spelaea (Goldfuss, 1823)), who were absent in the northern and central regions of the East European Plain, the cave lion occurred throughout all this territory. P. spelaea inhabited river valleys occupied by flood-plain forests and thickets bordering with steppe and tundra-steppe on watersheds.

The existence in the severe conditions of the periglacial landscape was provided by a dense fur coat as well as by the capability to hunting herbivores of various sizes, up to bison and young mammoths, which gave a possibility for predators to consume fresh meet by summer as well as by winter. Judging from the presence of canine dimorphism similar to that in the modern lion, the cave lion lived and hunted in groups (Yamaguchi et al., 2004), which was a part of its survival strategy.

ACKNOWLEDGMENTS. We are grateful to E.K. Bakhmisov and T.O. Grineva (CHNM), A.A. Lastukhin (Cheboksary), Prof. P. Tassy (MNHN), Prof. A. Nadachowski (ISEA), Dr. A. Currant (NHM) and late Dr. N.L. Fomicheva (GMMKU) providing collections for study.

\section{References}

Averianov A.O., Baryshnikov G.F., Garutt V.E., Garutt N.V. \& Fomicheva N.L. 1992. [Volga River Fauna of Pleistocene Mammals in Geological-Mineralogical Museum of Kazan University]. Kazan: Izdatelstvo Kazanskogo Universiteta. 164 p. [in Russian].

Baryshnikov G. \& Boeskorov G. 2001. The Pleistocene cave lion, Panthera spelaea (Carnivora, Felidae) from Yakutia, Russia // Cranium. Vol.18. No.1. P.7-24.

Baryshnikov G., Hoffecker J. \& Burgess R. 1996. Paleontology and zooarchaeology of Mezmaiskaya Cave (northwestern Caucasus, Russia) // Journal of Archaeological Science. Vol.23. No.3. P.313-335.

Burger J., Rosendahl W., Loreille O., Hemmer H., Eriksson T., Götherström A., Hiller J., Collins M.J., Wess T. \& Alt K.W. 2004. Molecular phylogeny of the extinct cave lion Panthera leo spelaea // Molecular Phylogenetics and Evolution. Vol.30. No.3. P.841-849.

Burova N.D. 2002. [Peculiarities of accumulation of mammal bone remains in the Upper Paleolithic site of Yudinovo] // Sinitsyn A.A., Sergin V.Y. \& Hoffecker J.F. (eds.). [Peculiarity of Development of the Upper Palaeolithic in Eastern Europe. Kostenki in the Context of the Palaeolithic of Eurasia. Research. Vol.1] Sankt-Peterburg. P.196-205 [in Russian].

Chubur A.A. 2001. [Byki. New Paleolithic Microregion and its Position in the Upper Paleolithic of Russian Plain]. Bryansk: Bryansk segodnya. 132 p. [in Russian].

Enloe J., David F. \& Baryshnikov G. 2000. Hyenas and hunters: Zooarchaeological investigations at Prolom II Cave, Crimea // International Journal of Osteoarchaeology. Vol.10. No.5. P.310-324.

Kalinovski P.F. \& Kuzmina I.E. 1993. [First find of remains of cave lion in Belarus] // Doklady Academii Nauk Belarusi. T.37. No.6. P.108-110 [in Russian].

Khromov A.A., Arkhangelsky M.S. \& Ivanov A.B. 2001. [Large Quaternary Mammals of Middle and Lower Volga River Basin]. Dubna. 256 p. [in Russian]

Kurtén B. 1968. Pleistocene Mammals of Europe. London: Weidenfeld and Nicolson. 317 p.

Kurtén B. 1985. The Pleistocene lion of Beringia // Annales Zoologici Fennici. Vol.22. No.1. P.117-121.

Kurtén B. \& Anderson E. 1980. Pleistocene mammals of North America. New York: Columbia Universty Press. $443 \mathrm{p}$.

Schütt G. \& Hemmer H. 1978. Zur Evolution des Löwen (Panthera leo L.) im europäischen Pleistozän // Neues Jahrbuch für Geologie und Paläontologie. Hf.4. S.228255.

Soffer O. 1985. The Upper Paleolithic of the Central Russian Plain. San Diego, New York, London et al.: Academic Press. 539 p.

Sotnikova M. \& Nikolskiy P. 2006. Systematic position of the cave lion Panthera spelaea (Goldfuss) based on cranial and dental characters // Quaternary International. Vol.142/143. P.218-228.

Sukachev V.N., Gromov V.I. \& Bader O.N. 1966. [Upper Paleolithic site Sungir'] // Trudy Geologicheskogo Insti-

1-Malaya Ilovitsa; 2 - Starye Duruitory; 3 - Vykhvatintsy; 4 - Tiraspol'; 5 - Odessa; 6 - Smorgon'; 7 - Smolensk; 8 - Yudinovo; 9 - Chernigov; 10 - Kirillovskaya; 11 - Mezhirichi; 12 - Kremenchug; 13 - Kodak; 14 - Shaitan-Koba; 15 - Adzhi-Koba; 16 Buran-Kaya; 17 - Syuren'1; 18 - Syuren' 2; 19 - Prolom 2; 20 - Avdeevo; 21 - Byki 1; 22 - Kostenki 1, 2, 4, 8; 23 - Shubnoye; 24 - Mezmaiskaya Cave; 25 - Gubs River; 26 - Sobolevo; 27 - Rossolovo; 28 - Sungir'; 29 - Tula; 30 - Bolshaya Shat'ma River; 31 - Chuvashiya (no exact locality); 32 - Mansurovo; 33 - Pustyn' 2; 34 - Tunguz; 35 - Devichi Gorki; 36 - Khoroshevkiy; 37 Medvezhiya Cave; 38 - Secrets Cave. 
tuta AN SSSR. T.162. P.1-140 [in Russian].

Turner A. 1984. Dental sex dimorphism in European lions (Panthera leo L.) of the Upper Pleistocene: Palaeoecological and palaeoethological implications // Annales Zoologici Fennici. Vol. 21. No.1. P.1-8.

Vereshchagin N.K. 1971. [The cave lion and its history in the Holarctic and on the territory of the USSR] // Trudy Zoologicheskogo Instituta AN SSSR. T.49. P.123-199 [in Russian].

Vereshchagin N.K. \& Baryshnikov G.F. 1992. The ecological structure of the "Mammoth Fauna" in Eurasia // Annales Zoologici Fennici. Vol.28. No.3-4. P.253-259. Yamaguchi N., Cooper A., Werdelin L. \& Macdonald D.W. 2004. Evolution of the mane and group-living in the lion (Panthera leo): A review // Journal of Zoology. Vol.263. No.4. P.329-342. 